\title{
Family fortresses in Zika Congenital Syndrome according to Betty Neuman
}

\author{
Fortalezas familiares na Síndrome Congênita do Zika à luz de Betty Neuman \\ Fortalezas familiares en el Síndrome Congénita del Zika a la luz de Betty Neuman
}

Laís Helena de Souza Soares Lima' ORCID: 0000-0002-0483-549X

Estela Maria Leite Meirelles Monteiro' ORCID: 0000-0002-5736-0133

Maria Wanderleya de Lavor Coriolano' ORCID: 0000-0001-7531-2605

Francisca Márcia Pereira Linhares' ORCID: 0000-0001-9778-5024

Ana Márcia Tenório de Souza Cavalcanti' ORCID: 0000-0001-6468-8826

'Universidade Federal de Pernambuco. Recife, Pernambuco, Brazil.

How to cite this article:

Lima LHSS, Monteiro EMLM, Coriolano MWL, Linhares FMP, Cavalcanti AMTS. Family fortresses in Zika Congenital Syndrome according to Betty Neuman. Rev Bras Enferm. 2020;73(2):e20180578. doi: http://dx.doi.org/10.1590/0034-7167-2018-0578

\section{Corresponding Author:}

Laís Helena de Souza Soares Lima

E-mail: laishelena18@gmail.com

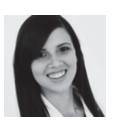

EDITOR IN CHIEF: Antonio José de Almeida Filho ASSOCIATE EDITOR: Fátima Helena Espírito Santo

Submission: 07-19-2018

Approval: 10-03-2018

\section{ABSTRACT}

Objectives: to identify elements that contribute to strengthen the family system of children with Zika virus congenital syndrome according to Betty Neuman's theory. Methods: qualitative research, carried out in the outpatient service of a public hospital in the city of Recife, Brazil, with 13 mothers, by semi-structured interviews. The IRAMUTEQ software was used for data analysis and the interpretation was carried out according to Betty Neuman's Systems Model Theory. Results: the dendrogram originated five categories, which we named: Family Routine, Health Service Assistance, Changes in Lifestyle, Support Network, and Social Repercussions of Care for the the Family Context. Final considerations: nursing actions based on Betty Neuman's theory provide subsidies for the recognition of elements that strengthen the defense lines of the family system. These resources can be explored, aiming to maintaining the well-being and balance in the context of the family system. Descriptors: Family; Family Relations; Microcephaly; Zika Virus; Nursing Theory.

\section{RESUMO}

Objetivos: identificar elementos que contribuem para fortalecer o sistema familiar da criança com síndrome congênita do Zika vírus à luz da teoria de Betty Neuman. Métodos: pesquisa qualitativa, realizada no ambulatório de um hospital público do Recife, com 13 mães, por meio de entrevista semiestruturada. Para a análise dos dados foi utilizado o software IRAMUTEQ e interpretação à luz da Teoria do Modelo de Sistemas de Betty Neuman. Resultados: o dendograma deu origem a cinco classes nomeadas: Rotina Familiar, Assistência do Serviço de Saúde, Mudanças no Estilo de Vida, Rede de Apoio e Repercussões Sociais do Cuidado para o Contexto Familiar. Considerações finais: ações de enfermagem fundamentadas na teoria de Betty Neuman fornecem subsídios para o reconhecimento de elementos que fortalecem as linhas de defesa do sistema familiar. Esses recursos podem ser explorados, com vistas à manutenção do bem-estar e o equilíbrio no contexto do sistema familiar.

Descritores: Família; Relações Familiares; Microcefalia; Zika Vírus; Teoria de Enfermagem.

\section{RESUMEN}

Objetivos: identificar los elementos que contribuyen al fortalecimiento del sistema familiar del niño con el síndrome congénita del virus del Zika bajo la teoría de Betty Neuman. Métodos: investigación cualitativa, realizada con 13 madres en el ambulatorio de un hospital público de Recife, y en la que se utilizó entrevista semiestructurada. El software IRAMUTEQ se utilizó en el análisis de datos, y la Teoría del Modelo de Sistemas de Betty Neuman en su interpretación. Resultados: el dendograma generó cinco clases intituladas: Rutina Familiar, Atención del Servicio de Salud, Cambios en el Estilo de Vida, Red de Apoyo y Repercusiones Sociales del Cuidado en el Contexto Familiar. Consideraciones finales: las acciones de enfermería con base en la teoría de Betty Neuman promueven subsidios para reconocer elementos que fortalecen las líneas de defensa del sistema familiar. Se pueden explorar estos recursos con el fin de mantener el bienestar y el equilibrio en el contexto del sistema familiar.

Descriptores: Familia; Relaciones Familiares; Microcefalia; Virus Zika; Teoría de Enfermería. 


\section{INTRODUCTION}

Family is a social system that performs functions of affective, education, socialization, and reproductive nature in society ${ }^{(1)}$. Although the concept of family has changed over the generations, the affective function of family is a dimension that has persisted throughout time ${ }^{(2)}$.

Part of the family cycle is the birth of a child, an unique moment that, in many cases, represents social achievement ${ }^{(3)}$. Given this scenario, it is worth stressing that during the gestational period the family intensifies the expectations of how the child will be, and the birth of a child with malformation is a confrontational situation between the imagined and the real child, which may cause a big impact on the family system ${ }^{(4)}$.

Among malformations, microcephaly stands out, a neurological malformation characterized by the skull's measurement, carried out 24 hours after birth and in the first week of life, through standardized equipment and technique, in which the cephalic perimeter presents measurement of less than -2 standard deviations below the specific mean regarding sex and gestational age ${ }^{(5-6)}$. It has a complex and multifactorial etiology and can occur due to infectious processes during pregnancy ${ }^{(7)}$.

Although considered a rare occurrence, in 2015, an epidemic of microcephaly began, diagnosed by means of peculiar radiological changes, such as calcifications, ventriculomegaly, and cortical development disorder, suggestive of congenital infection since the main causes associated with cerebral calcifications (cytomegalovirus and toxoplasmosis) were discarded, as well as other genetic or environmental causes ${ }^{(7)}$, which later came to be called Zika virus congenital syndrome (ZVCS).

This situation has aroused the attention of Brazilian health authorities and experts, initiating investigations to identify the possible causes of this event ${ }^{(8)}$. In November 2015, the Brazilian Ministry of Health has confirmed the relationship of this situation with Zika virus infection (ZIKV), and the World Health Organization issued an epidemiological alert regarding the association of this virus with congenital malformations and neurological syndromes ${ }^{(9-10)}$. The following year, 2016, the Northeast region had 1,447 cases under investigation and 159 cases confirmed. Pernambuco, considered the second state with the highest number of suspicions, presented 404 cases $^{(7-8)}$.

The occurrence of ZVCS comes along with motor and cognitive changes, with cognitive impairment occurring in about $90 \%$ of the $\operatorname{cases}^{(8)}$. The relationship between the family members of a child with ZVCS is extremely significant and comes with reactions that may be positive or negative. With the birth of the child, the family goes through a readjustment of its dynamics and, when all the members begin to perform tasks and to assume roles to allow the operation of this system, they demonstrate adaptation to the situation, being considered a positive reaction ${ }^{(11)}$.

As a member of the health team, the nurse also has a supportive role, being a facilitator within the social support network in which the family is inserted. The nurse works encouraging the family to build possibilities for facing new situations ${ }^{(12)}$.

Betty Neuman's nursing theory, entitled Systems Model Theory, is based on the stress and in the reaction to the stressor factor. In this theory, the family is seen as an open system that seeks to maintain the balance among the various environmental factors, with the greater objective of maintaining stability through the investigation of the effects of the stressors invasion, helping the system to make the adjustments required for an optimal well-being ${ }^{(13)}$.

For Betty Neuman, the system has defense lines to stressors factors: the normal defense line, which keeps the individual in a well-being or stable state; and the flexible defense lines, which, being a dynamic system, flexibility exists so that one may adapt to the stressors, acting as a buffer and a filter, when the environment offers support. It is important to understand the protective barriers of this system to strengthen them in the pursuit of the individual's health stability ${ }^{(13-14)}$.

Understanding the dynamics of the family of a child with ZVCS according to Betty Neuman's theory, the nurse can promote the valuing of family relations and recognition of needs through the identification of the fortresses promoted by the system's defense lines, aiming to enable the development of educational interventions that promote family autonomy to plan with a view to comprehensive care.

\section{OBJECTIVES}

To identify elements that contribute to strengthen the defense lines of the family of a child with ZVCS regarding interaction with the environment, according to Betty Neuman's theory.

\section{METHODS}

\section{Ethical aspects}

This study was approved by the Research Ethics Committee of the Health Sciences Center of the Federal University of Pernambuco. Before the data collection procedure, the participants were informed about the objectives of the research through the informed consent form, which was signed in two copies by them, one for them to keep and the other for the researcher. To ensure the confidentiality of the information and anonymity of participants, they were identified by the code name "participant" followed by the number of the interview.

\section{Theoretical-methodological reference}

\section{Type of study}

This is a descriptive and exploratory study with qualitative approach. The use of this methodology applied to health enables the understanding of the meanings of a phenomenon for the people. Thus, they become culturally shared and the social group are organized around those representations and symbolism ${ }^{(15)}$.

Seeking the meaning and intentionality of the acts, in addition to deepening the reality reported, our intention with this approach was to understand the subjectivity expressed in the participants' testimonies.

\section{Methodological procedures}

\section{Study scenario}

The study was conducted in the otolaryngology outpatient service of a public hospital from the State Health Network, located in the city of Recife, state of Pernambuco, Brazil. 
This hospital is considered as reference in otolaryngology in the state of Pernambuco, and is also a reference for children with ZVCS regarding the study and treatment of diseases that affect the ear, nose, and throat. It also cares for patients from the SUS network, for evaluation and follow-up.

In the outpatient service, the hearing screening of children with ZVCS was performed by speech therapy professionals through the referencing done by the State of Pernambuco Health Department (SES-PE). Those who present some type of change will be accompanied in the mentioned sector. On the other hand, those that do not present any changes are referenced back to the original location.

\section{Data source}

Sampling was achieved by the convenience or voluntary method $^{(16)}$, in which we recruited to participate in the research all families of children with ZVCS that were in follow-up in the sector and those who were waiting for the hearing screening. Thirteen mothers participated in this study, highlighted as the main caregivers, who met the following inclusion criteria: being the relative who gave direct informal care to the child with ZVCS, aged over 18 years, and who accompanied the child to appointments.

\section{Data collection and organization}

The data were collected from February to April 2017, by means of semi-structured interviews carried out individually by the lead researcher, in a single moment in a reserved room, courtesy of the service, while the family waited for care in the sector.

The interviews were guided by a script with five main questions: How is the child care routine? What has changed in your life and in the life of your family after the child's birth? What are the main support you received or receive for taking care of the child? How is the support of health professionals concerning the child's care? About your relationship with healthcare professionals, are you able to expose your doubts and needs concerning the child?

To define the number of interviews, the saturation criterion was used ${ }^{(15)}$. The attestation of data saturation, in this research, was carried out following five steps ${ }^{(16)}$. The first is the definition of analysis categories referring to the study's goal; the second is the definition of the study script, related to the data collection instrument; the third is the raising of new elements vs. elements confirmed in each collection that dealt with the collection of elements in the interview; the fourth is the record of what was found in each collection and refers to the record of this collection of elements; and the fifth step is the confirmation of saturation in each category that refers to the saturation of the goals.

After the completion of the five steps, we found that the overall theoretical saturation of data occurred in the $10^{\text {th }}$ interview, in which no new information was identified and considered relevant to the research. Three more interviews were conducted to increase the safety margin for saturation.

\section{Data analysis}

For the organization, analysis, and interpretation of data, the interviews were transcribed and arranged in a single corpus with the aid of IRAMUTEQ, a software that provides subsidies to assist a textual analysis, of free access, which anchors in the software $R$ and python language to develop diverse textual statistical analyses. In this research, we used the Descending Hierarchical Classification (DHC), in which the text segments (TS) were organized and classified from their vocabulary, and established in a dendrogram that illustrates the relationships among the categories ${ }^{(17)}$.

From the categories and dendrogram, an interpretive analysis was performed by the researcher, based on the theoretical framework of Betty Neuman, seeking to identify the elements to strengthen the defense lines of families in the care of the child with ZVCS that emerged from the participants' testimonies.

\section{RESULTS}

\section{Characterization of interviews by the IRAMUTEQ software}

The data from the interviews generated the textual corpus analyzed from DHC. It was divided into 371 TS, listing 1,691 words that occurred 13,211 times. The DHC retained $81.40 \%$ of the total TS, generating five categories with 302 elementary context units (ECU).

We named the categories: Category 1 - Support Network, with $18.54 \%$ of the ECU; Category 2 - Family Routine, with $22.52 \%$ of the ECU; Category 3 - Social Repercussions of Care for the the Family Context, with $16.89 \%$ of the ECU; Category 4 - Changes in Lifestyle, with $20.86 \%$ of the ECU; and Category 5 - Health Service Assistance, with $21.19 \%$ of the ECU. For this study, we analyzed only the text segments that emphasized family fortresses expressed in the participants' testimonies regarding the dynamic experienced after the child's birth.

\section{Reports of the interviews by categories of IRAMUTEQ ac- cording to Betty Neuman's Systems Model Theory}

Category 1, named Support Network refers to the characteristics related to the support received by mothers and/or family by relatives, friends, neighbors, government institutions and services regarding the child's care. When the support is received and is within the expected by the family, it experiences sensations that contribute to the strengthening of the family system.

These elements are present within the family itself, but are also perceived in neighbors, friends, health professionals, and government services.

Who takes care of her is me, the father, she has a Government's benefit, and the family that helps. (Participant 1)

I say that they support me a lot, the professionals in the rehabilitation center where he is being treated. (Participant 2)

My mother is the one who helps me, actually, my support right now is my mother. When I need it, it is my mother, and my partner also helps me. (Participant 5)

I have the support from my family, which is me, my mother, and my husband. Who provides for us is my mother, who I live with, her father lives with me. (Participant 6) 
Concerning help, I get a car from City Hall, which is especially for microcephaly. It comes to pick me up whenever I call. My mother always helps me, and we have a neighbor who is the same as a grandmother to him. Such aid, is very good. (Participant 9)

The support, we went looking for doctors, in the beginning, and we had a lot of assistance, they guided us and, in addition to teaching the care, even encouraged us. This was a great support we received. (Participant 11)

One of the participants reported the existence of support among the families of children in the same condition when they meet in the appointments and therapies.

It is the exchanges between mothers, we talk with each other. (Participant 10)

We also observed, as part of family support, the existence of the belief in God, as described in the following testimonies.

Firstly, God. (Participant 3)

Sometimes it happens that you get home and ask God for a lot of support, because if it was not for God, I think I would not even be here. (Participant 12)

When my forces are falling apart, I ask God for strength, and we will get there. (Participant 7)

Category 2, Family Routine, concerns dynamic questions experienced by family members. For some families, the routine after the birth of the child does not cause any discomfort, therefore, it does not change its defense lines. The well-being and stability of the family are emphasized.

We observed in the testimonies that the routine is unchanged for family members who take on the care process in a natural way.

At home, is the usual baby routine, he stands there silent, sitting, watching [...]. And, when there is an appointment, we take him to the appointment, that is the routine. (Participant 2)

When you are at home, the routine is always the same: playing, there is the time for stimulation, [...] / do some stretching the physical therapist and occupational therapist taught me, and there is also a lot of preparation, taking the medication. (Participant 6)

On Mondays, Tuesdays, and Wednesdays, we go to the doctor. the rest of the days is for normal care at home. (Participant 10)

Our days work like this: he [child's father] arrives from work at 7 a.m. and stays with her, then I go to work, I am back at midday so he goes to sleep and I go to therapy with her [...] and, when there is no therapy, we organize the routine with exams, with appointments. (Participant 13)

Having to move to take the child to appointments and therapies also generates in the family a feeling of doing something that leads to the improvement of the child's quality of life.

Every day I go to the rehabilitation center to do his physical therapy in the morning, in the afternoon I am home. At home I put him to rest, and then I begin to do the therapies as well, so he can develop faster. (Participant 9)

Category 3 was named Social Repercussions of Care for the the Family Context. It expresses the relationship developed in the daily care of the child experienced by the family and how they reflect on their well-being. The testimonies indicate the strengthening of the family regarding the reward to witness the overcoming actions of the child, in addition to the sense of happiness of taking care of the child.

Is that thing, we fight and fight and when we see a result, there is a lot of love involved, the love is doubled and you see that your baby gets there and does everything all right, that is very joyful. I am not going to say it is a bed of roses, but it is very rewarding. (Participant 2)

It is very gratifying to me because I give my best to take care of her. (Participant 3)

Her presence for me is the most wonderful thing that could have happened in my life, she is the gift that God chose for me and if He gave her to me like this, it is because it will enable me to continue taking care of her. (Participant 4)

For me, as a mother, taking care of him is wonderful. I think that taking care of him is very good, wonderful. (Participant 11)

Category 4 was named as Changes in Lifestyle and is directly related to changes occurring in the family's lifestyle, especially in the life of the mother, evidenced in this study as the child's primary caregiver. For this category, the testimony of one participant revealed that staying in her job was a factor of protection for her defense lines. It corroborated to her well-being and contributed to family strengthening.

Working away from home has been good for me, because I can relax, for example, those hours I am away from home, I can forget a little bit about home, my daughter, everything. (Participant 13)

Category 5, Health Service Assistance, is related to how the health services assist families, including assistance provided by health professionals and their involvement with the families. The quality of this assistance to families in the appointments and therapies is extremely relevant to their well-being.

It was observed that, for the participants, the number of appointments and professionals who assist the child is essential to ensure the family's comfort concerning care.

She gets a lot of appointments in the hospital, she is very well, thank God, very well monitored. She goes to the rehabilitation center, orthopedist, speech therapist, I think it is great. (Participant 1)

For my daughter, thank God, nothing has missed. The professionals who treat her are good, in fact, they are of excellent quality. (Participant 4)

I like the professionals, they are good professionals, I have been lucky so far, they are well qualified, and I see already her improvement. (Participant 5) 
Health professionals, to her, have been good, very good, because without them I do not know what would become of us. (Participant 8)

The relationship with health professionals was also evidenced in this category. In the testimonies, the participants show how this interaction is beneficial to the family system.

It is very good, where I do it is a family, they sit, talk with us about what we want our baby to work with, how they think my baby is and what needs to be improved, they work, talk ... it is very good [...]. I have no complaints, no, when I arrive, I am very well treated, he is well attended, they listen to us, listen to what he needs, guide me, it is good. (Participant 2)

They advise us when we feel a bit distressed [...]. It is a very good relationship, of friendship, because they help me take care of my daughter. (Participant 8)

They are very helpful, dedicated, great even, we see that they work with love [...]. Even in the outpatient service, where the head nurse stays, when I need anything, I call her, or she goes to my house. I always receive an excellent support from the professionals [...]. My relationship is like we were friends already, because, what I need, I can ask questions at any time, because I have the phone numbers of his therapists, they answer my questions when I am there too, it is a great relationship, really great. (Participant 9)

It is great, I can ask questions, talk, we learned a lot from them, because we talk, we are always talking with them. (Participant 11)

\section{DISCUSSION}

The birth of a child with special health needs causes a profound impact on the family and, consequently, in the interactions established within it, causinf strain on the family structure. Relations, then, need to be adapted in an attempt to be strengthened, when this does not happen, they can disintegrate ${ }^{(18)}$.

In Family Routine, by experiencing a new situation of specific care to the child, the routine is readapted. The way families deal with the arrival of the child with ZVCS at the home and the need for continuous care are variable aspects ${ }^{(19)}$. When there is no obvious stress reported by the family, its defense lines remain intact.

As seen in this study, a research conducted in 2016 with families of minors with special health needs observed that some respondents reported that there was no aversion on the part of the family regarding the consequential dependences of the child in daily activities ${ }^{(20)}$.

Concerning the Health Service Assistance, the reports address how is the relationship and the quality in the services provided by institutions and by health professionals. Through the speeches, it was possible to observe that the families receive the assistance of a multidisciplinary team that guides them and allows the child to have a better quality of life, as seen in this study ${ }^{(21)}$.

For most families, the health care provided by professionals in the appointments and therapies had good quality, which was characterized for them as something extremely relevant to their well-being, maintaining their defense lines strengthened. It is essential that families possess professional health care that provides responsiveness regarding their situation, comforting their feelings, as well as giving hope and encouragement ${ }^{(3,19)}$.

The less the health professionals responsible for the assistance of these children focus on the child's difficulties and more on his/ her potentials and qualities, the better it will be for the family to realize and accept the child ${ }^{(3,19)}$.

According to Betty Neuman ${ }^{(13)}$, system stability over time is represented by the normal defense line, which is a variation of responses to the environment. Both the system and the environment may be affected in this interaction, and this can happen in a positive way. Ideally, the system has potential to adapt by itself, guaranteeing its stability.

The flexible defense lines works as a buffer and operates as a shield for the commonly stable state of the system. Although it is responsible for stability, it is dynamic and can change in a short period of time. As it distances itself from the normal defense line, the protection level of the system increases ${ }^{(21)}$.

The permanence of one participant in her job, due to the possibility of flexible time load and work shift, as well as the dedication of her husband (the child's father), who divides with her their daughter's care schedule, highlights the positive aspect portrayed concerning the time dedicated to different activities from those experienced at home with the child. This factor strengthens the caregiver's defense lines, especially for being a moment of relaxation, as revealed in her testimony.

A possibility of balance was evidenced in this couple's routine, due to the decision to establish a shared family planning of the child's care daily routine, balancing the maintenance of both jobs. This contributed to the exercise of active fatherhood, minimizing the impact on economic stability and, above all, on the possibilities of development of affective bonds in the family nucleus.

In this study, the family's well-being regarding the reward of witnessing the overcoming actions of the child is clear, in addition to the sense of happiness of taking care of the child. Expressing these feelings, the family presents its defense lines strengthened by the restoration of the system.

The family expresses an inexplicable sensation, generated by the pleasure of caring for a child with special needs, and attributes great joy and satisfaction to this relationship ${ }^{(22)}$. Even with daily exhausting demands and the care, sometimes centered on the caregiver, the meaning attributed to it is perceived as rewarding.

The caregiver feels privileged, believing that she is also special and that she is constantly learning from the child. Regardless of the child's diagnostic condition, she loves and cares, giving her best. In addition, she understands her role not only as restricted to care, but experiences it as lessons that life offers and by means of which she can observe and learn ${ }^{(22)}$.

Differently from what was exposed in this study, in a research carried out with minors with special health needs and their families ${ }^{(19)}$, some parents, even witnessing their child's progress, did not feel gratified because their revolt and rejection were stronger, thus needing a long process of adaptation for considering their child a priority, and not his/her diagnostic condition.

Concerning the Support Network, a study that dealt with social support to children with special health needs ${ }^{(20)}$ revealed that the families reported receiving help from philanthropic institutions as indispensable to improve the child's quality of life. 
Regarding health professionals, the construction of a network of effective social support to these families, with a health team prepared to meet the care demands of the children with ZVCS is fundamental. Therefore, primary care services must be able to perceive the domestic environment as an extension for care practice $^{(20)}$.

We highlight that one of the participants reported the existence of support among the families of children in the same condition in the appointments and therapies. This fact strengthens the family system. Families have a need to share experiences with other families living similar situations. This allows for knowledge reciprocity and clarification of doubts among family members. The support from a family of a child with special needs is a stimulus to another family in a similar situation in overcoming the problems experienced in the daily routine of home care ${ }^{(20)}$.

The participants also reported, as part of the family support network, the existence of belief in God as a fortress and, for one of them, given all the changes suffered, what impacted her was reduction of frequency to church, thus relating to her religious and spiritual life.

In search of meanings to their experience and welcoming in times of suffering, the families find in religion the attributes necessary to protect their life story as a result of the current situation, and also answers to questions on the reason for the child to have been born. Those answers involve various ways to give meaning to the condition imposed to the family and, positively, as the mission to teach others or the possibility of establishing a relationship with people to assist in their path ${ }^{(22)}$.

Family members believe that God, even not answering all prayers, has the power to heal the child and free him/her of complications, strengthening the family to keep fighting to give their best for the child ${ }^{(22)}$.

As Betty Neuman's theory recognizes the system holistically, being composed of physiological, psychological, socio-cultural, development, and spiritual variables so that stability can be achieved, it is important that relationships are balanced with the amount of energy available in the system. Stability is dynamic and works according to the feedback, in which the system should regulate itself by expanding and strengthening the defense lines and preventing illness ${ }^{(13)}$.

Nurses, intervening in the system from the particularities of each family, must base their actions on Betty Neuman's theories to contribute to the strengthening of families' defense lines aiming to predict risk factors surrounding the system that threaten its balance ${ }^{(14)}$, to assist the system to adapt or adjust and retain, restore, or maintain some degree of stability among the system variables and environmental stressors focusing on energy conservation $^{(13,21)}$.

Based on Betty Neuman's prevention levels, the health education strategy is considered the primary level of prevention, as its objective is the valuation of family emancipation and the promotion of the welcoming through the dialogue. Primary prevention aims to prevent a possible negative reaction from the system. Its primary goal is is to promote health and maintain healthiness ${ }^{(13,21)}$.

As nursing actions for primary prevention, based on the health education practice, Betty Neuman aims to prevent the invasion of stressors, provide information to retain or fortify the strengths of the system, support positive confrontation and functioning, motivate working towards health, educate or reeducate, in an attempt to strengthen the family resources to a positive understanding of stressors toward the ideal health and well-being of the system ${ }^{(13,21)}$.

It is important to know and understand the context in which a family that receives a child with ZVCS is inserted, passing through social and economic factors, and especially covering the theme of ZIKV. From the recognition of coping strategies generated to strengthen the family system, it is possible to develop a care plan designed to fully meet their needs.

For nursing, we highlight that considering the elements that involve the strengthening of the family system according to Betty Neuman's theory demands a look directed to new perspectives and needs related to health assistance. It is important, on the part of nurses, still in the family context, to strengthen the therapeutic relationship in the triad family/individual/community, essential to the practice of a care committed to health promotion.

\section{Study limitations}

This research presents the limitations typical of qualitative descriptive studies, especially regarding the investigation of the family context, represented by participants as the mothers of the children, which hinders the generalization of results. Thus, we recommend the development of studies with an interventive approach, aiming to propose strategies to consolidate the strengthening of the family system of children with ZVCS.

\section{Contributions to the nursing field}

The research presents contributions to the nursing by bringing visibility to a portion of the population that received great prominence in Brazil and in the world in the year of 2015, but that still requires attention regarding the social, political, and cultural context in which they are inserted. This study provides subsidies for healthcare professionals involved in the care of children with ZVCS, to see the family as part of the care process, expanding the view in the planning and implementation of care, especially concerning nurses as members of this care and healthcare network. Combine care to the nursing theory provides a reflective practice with the development of intervention strategies aimed at promoting health.

\section{FINAL CONSIDERATIONS}

The elements that contribute to the strengthening of the defense lines of the family system of children with ZVCS according to Betty Neuman's theory are resources that can be explored, aiming to maintaining the well-being and balance in the context of the family system.

One of the main functions of the nurse is to intervene in the system focusing on preventing disease and promoting health. Nursing actions based on Betty Neuman's theory offer subsidies to choose measures that contribute to a balanced family posture, expanding the understanding of its dynamics, as well as recognizing elements that strengthen this system's defense lines. 
Coping measures in the daily family life based on educational practices can contribute to the reflection on the part of the family about the child and his/her diagnostic condition, aiming at the maintenance of health and safety of the care and health decisions related to the child, due to a critical and reflexive knowledge construction involving the possibilities of overcoming difficulties for the integral care of children with ZVCS.
Concerning health institutions and their connection with the nurses' care for the family component, it is valid to point out that acting on family strengthening - although not easy - is of utmost importance when we reflect on the completeness of care. Thinking about integral care is not only about observing the child in a holistic way, but to expand the institutional and professional look to consider the family component in a similar way.

\section{REFERENCES}

1. Silva ML, Polli RG, Sobrosa GMR, Arpini DM, Dias ACG. Da normatização à compreensão: caminhos construídos para a intervenção familiar. Mud Psicol Saúde. 2012;20(1-2):13-21. doi: 10.15603/2176-1019/mud.v20n1-2p13-21

2. Silva CCB, Ramos LZ. Reações dos familiares frente à descoberta da deficiência dos filhos. Cad Ter Ocup UFSCar. 2014;22(1):15-23. doi: 10.4322/cto.2014.003

3. Rodrigues DRS, Franco EL, Kosac KF, Franco LLMM, Silveira MMM, Usevicius PMA. Relatos orais e reflexões sobre a experiência da gestação e construção do bebê imaginário. Indag Didact [Internet]. 2013 [cited 16 Dec 2016];5(2):978-88. Available from: http://revistas.ua.pt/index. $\mathrm{php} / \mathrm{ID} /$ article/view/2504/2370

4. Nunes ML, Carlini CR, Marinowic D, Neto FK, Fiori HH, Scotta MC, et al. Microcephaly and Zika virus: a clinical and epidemiological analysis of the current outbreak in Brazil. J Pediat. 2016;92(3):230-40. doi: 10.1016/j.jpedp.2016.04.001

5. Alcantara D, O'Driscoll M. Congenital microcephaly. Am J Med Genet C Semin Med Genet. 2014;166C(2):124-39. doi: 10.1002/ajmg.c.31397

6. Miranda-Filho DB, Martelli CMT, Ximenes RADA, Araujo TVB, Rocha MAW, Ramos RCF, et al. Initial description of the presumed congenital Zika syndrome. Am J Public Health. 2016;106(4):598-600. doi: 10.2105/AJPH.2016.303115

7. Ministério da Saúde (BR). Secretaria de Vigilância em Saúde. Protocolo de atenção à saúde e resposta à ocorrência de microcefalia relacionada à infecção pelo vírus Zika. Departamento de Vigilância das Doenças Transmissíveis [Internet]. Brasília: Ministério da Saúde; 2016 [cited 2017 Oct 16]. Available from: http://bvsms.saude.gov.br/bvs/publicacoes/protocolo_resposta_microcefalia_relacionada_infeccao_ virus_zika.pdf

8. Ministério da Saúde (BR). Ministério da Saúde confirma relação entre vírus Zika e microcefalia [Internet]. Brasília: Ministério da Saúde; 2015 [cited 2017 Oct 16]. Available from: http://www.blog.saude.gov.br/index.php/ combate-ao-aedes/50399-ministerio-da-saude-confirma-relacao-entre-virus-zika-e-microcefalia

9. World Health Organization (WHO). Epidemiological alert: neurological syndrome, congenital malformations, and Zika virus infection. Implications for public health in the Americas [Internet]. Geneva: WHO; 2015 [cited 2017 Oct 16]. Available from: http://www.paho.org/hq/ index.php?option=com_docman\&task=doc_view\&ltemid=270\&gid=32405\&lang=en

10. Santos AL, Cecilio HPM, Teston EF, Marcon SS. Knowing the family functionality under the view of a chronically ill patient. Texto Contexto Enferm. 2012;21(4):879-86. doi: 10.1590/S0104-07072012000400019

11. Marques AKMC, Landim FLP, Collares PM, Mesquita RB. Apoio social na experiência do familiar cuidador. Ciênc Saúde Colet. 2011;16 (Supl 1):945-55. doi: 10.1590/S1413-81232011000700026

12. Neuman BM. The Neuman systems model. 5th ed. Ohio: Appleton \& Lange; 1995.

13. Martins TSS, Silvino ZR. Um marco conceitual para o cuidado a criança hospitalizada à luz da teoria de Neuman. Cogitare Enferm. 2010;15(2):340-4. doi: 10.5380/ce.v15i2.17873

14. Guerini IC, Cordeiro PKS, Osta SZ, Ribeiro EM. Relatives' perception regarding the stressors resulting from the care demands of technologydependent children and adolescents. Texto Contexto Enferm. 2012;21(2):348-55. doi: 10.1590/S0104-07072012000200012

15. Flick, U. Desenho da pesquisa qualitativa. Porto Alegre: Bookman; 2009.

16. Falqueto J, Farias J. Saturação teórica em pesquisas qualitativas: relato de uma experiência de aplicação em estudo na área de administração [Internet]. In.: Atas do 5 Congresso Ibero-Americano em Investigação Qualitativa (CIAIQ 2016), 2016 July 12-14. Porto: CIAIQ: 2016 [cited 2017 Sep 02];560-9. Available from: http://proceedings.ciaiq.org/index.php/ciaiq2016/article/view/1001

17. Camargo BV, Justo AM. IRAMUTEQ: um software gratuito para análise de dados textuais. Temas Psicol. 2013;21 (2):513-8. doi: 10.9788/ TP2013.2-16

18. Polidori MM, Capalonga D, Franceschi D, Frantz M, Medeiros FAR, Pereira PCA, et al. O impacto da avaliação (diagnóstica) nos familiares de crianças com deficiência. Rev Compet. 2014;4(2):11-29. doi: 10.24936/2177-4986.v4n2.2011.69

19. Figueiredo SV, Sousa ACC, Gomes ILV. Children with special health needs and family: implications for Nursing. Rev Bras Enferm [Internet]. 2016;69(1):79-85. doi: 10.1590/0034-7167.2016690112i

20. Barbosa TA, Reis KMN, Lomba GO, Alves GV, Braga PP. Rede de apoio e apoio social às crianças com necessidades especiais de saúde. Rev Rene. 2016;17(1):60-6. doi: 10.15253/2175-6783.2016000100009 
21. McEwen M, Wills EM. Bases teóricas de enfermagem. Porto Alegre: Artmed; 2015.

22. Bolla BA, Fulconi SN, Baltor MRR, Dupas G. Cuidado da criança com anomalia congênita: a experiência da família. Esc Anna Nery Rev Enferm. 2013;17(2):284-90. doi: 10.1590/S1414-81452013000200012 